In 2015/16 North West CCGs have commissioned AQ COPD across 15 of the 21 Acute Trusts. An AQ incentive framework was also developed for providers and commissioners that supports "doing the right thing" collaborative events ensure that ongoing sharing of best practise happens and we have future plans to expand into Primary and Community Care.

\section{Occupational lung disease}

\section{P52 EPIDEMIOLOGY OF OCCUPATIONAL EXTRINSIC ALLERGIC ALVEOLITIS REPORTED TO SWORD 1996-2014}

${ }^{1} \mathrm{CM}$ Barber, ${ }^{2} \mathrm{M}$ Carder, ${ }^{2} \mathrm{R}$ Agius. ${ }^{1}$ Centre for Workplace Health, Buxton, UK; ${ }^{2}$ Centre for Occupational \& Environmental Health, Manchester, UK

\subsection{6/thoraxjnl-2015-207770.189}

Introduction Worldwide, the true epidemiology of occupational EAA is poorly understood. Data from national reporting schemes offers one method of examining the changing demographics of this disease, and comparing the most commonly reported causes. Methods Data was obtained for all cases of occupational EAA reported to the UK Surveillance of Work-related and Occupational Respiratory Disease (SWORD) scheme since 1996. The likely causative agents for each reported case were grouped into categories, and data compared for the earliest and latest available 5-year time periods (1996-2000 and 2010-2014). An estimate of the annual incidence of occupational EAA was calculated from the estimated number of cases in each time period divided by the average UK working population at that time (data from the Office for National Statistics).

Results Data for the early and late 5 -year time periods are presented in Table 1. The estimated incidence of occupational EAA was similar for the two time periods, but there has been a notable change in reported causation. Occupational EAA due to metalworking fluid, coolant or oil mist exposure has become the most commonly reported cause, responsible for almost a third of all cases. Over the same time period, EAA in mushroom workers has fallen from the joint commonest cause to no reported cases at all.

\begin{tabular}{|c|c|c|}
\hline & $1996-2000$ & 2010-2014 \\
\hline Reported cases & 45 & 39 \\
\hline Mean age & 54 & 54 \\
\hline Gender male:female & $2.7: 1$ & $3.3: 1$ \\
\hline \multicolumn{3}{|l|}{ Reported cause (\%): } \\
\hline Air con/humidifiers & 2 & 0 \\
\hline Avian proteins & 11 & 15 \\
\hline Cleaning agents & 9 & 0 \\
\hline Farming/hay/straw & 22 & 15 \\
\hline Isocyanates & 5 & 8 \\
\hline Mushrooms (edible) & 22 & 0 \\
\hline MWF/coolant/oil mist & 2 & 33 \\
\hline Other cause & 16 & 11 \\
\hline Other mould/fungus & 4 & 13 \\
\hline Unknown & 7 & 5 \\
\hline
\end{tabular}

Discussion The estimated annual incidence of occupational EAA in the UK has remained relatively stable at approximately 1-2 cases per million workers. Although this is likely to represent an underestimate, it is similar to the estimated incidence from reporting schemes in Australia, Catalonia, and the Czech Republic, but an order of magnitude lower than that reported in Finland. Over the last 20 years, EAA due to metalworking fluid exposure has emerged as the most commonly reported cause in the UK. This change has not been noted in other published reporting schemes, where EAA due to agricultural exposures remains the most common aetiology.

\section{P53 DETERMINATION OF SPECIFIC IGE ANTIBODIES TO MOUSE PROTEINS IN LABORATORY ANIMAL WORKERS}

1J Canizales, ' I Welch, ${ }^{1} B$ Fitzgerald, ${ }^{2} Z$ Lightfoot, ${ }^{2} W$ Banya, ${ }^{1} \mathrm{~J}$ Feary, ${ }^{1} \mathrm{P}$ Cullinan, ${ }^{1}$ M Jones. I'mperial College, London, UK; ${ }^{2}$ Royal Brompton Hospital, London, UK

\subsection{6/thoraxjnl-2015-207770.190}

Introduction Laboratory animal workers are at increased risk of developing specific $\operatorname{IgE}$ antibodies to laboratory animal proteins. The major allergen for mouse is Mus $\mathrm{m} 1$ which is predominantly found in the urine. Specific IgE to mouse is determined using either a commercial skin prick test solution of mouse epithelium or ImmunoCAP for either mouse urine or epithelium. Specific IgE to Mus $\mathrm{m} 1$ is used for routine diagnostic testing.

The aim of this study was to compare sensitisation using both ImmunoCAP and skin prick test as well as compare mouse urine and epithelium as allergens. At present there is no gold standard for sensitisation to mouse allergens.

Methods Laboratory workers exposed to mice were recruited to the SPIRAL (Safe Practice in Reduction of Allergy in Laboratories) study. Sensitisation was determined by the presence of specific IgE to Mus $\mathrm{m} 1$ and mouse epithelium using ImmunoCAP (Phadia) (positive result $\geq 0.35 \mathrm{kU} / \mathrm{l}$ ) and by skin prick test to mouse epithelium (positive result is a saline adjusted mean wheal diameter of $\geq 3 \mathrm{~mm}$ ).

Results Of the participants (321), 11 (3\%) were positive by skin prick test, 34(11\%) with specific IgE to Mus m 1 and 35 (11\%) with a positive specific IgE to mouse epithelium.

There were 25/321(8\%) participants with a discordant results between SPT and specific IgE to Mus $m 1$ (Table 1). There were 14 participants with a discordant result between specific IgE to Mus $\mathrm{m} 1$ and mouse epithelium (Table 1).

\begin{tabular}{llll}
$\begin{array}{l}\text { Abstract P53 Table 1 } \\
\text { epithelium in laboratory }\end{array}$ & $\begin{array}{l}\text { Specific IgE to Mus m } 1 \text { and mouse } \\
\text { animal workers }\end{array}$ & & \\
\hline & $\begin{array}{l}\text { Mus m 1 specific } \\
\text { IgE positive }\end{array}$ & $\begin{array}{l}\text { Mus m 1 specific } \\
\text { IgE negative }\end{array}$ & Total \\
\hline SPT positive & 10 & 1 & 11 \\
SPT negative & 24 & 286 & 310 \\
Total & 34 & 289 & 321 \\
Mouse epithelium specific & 26 & 9 & 35 \\
IgE positive & & 286 & 291 \\
Mouse epithelium specific & 5 & & 326 \\
IgE negative & 31 & 295 & \\
Total & & &
\end{tabular}

